\title{
The Effect of Rhododendron Honey on Mice Liver Tissue
}

\author{
Efecto de la Miel de Rododendro en el Tejido Hepático de Ratón
}

\author{
Aysel Kükner*; Gizem Ilter*; Gizem Söyler*; Pınar Göç Rasgele ${ }^{* * *}$; Meral Kekeçoglu ${ }^{* * * * *}$ \& Merve Kambur****
}

KÜKNER, A.; ILTER, G.; SÖYLER, G.; RASGELE, P. G.; KEKEÇOGLU, M \& KAMBUR, M. The effect of rhododendron honey on mice liver tissue. Int. J. Morphol., 34(3):842-847, 2016.

SUMMARY: Rhododendron honey, made by bees from rhododendron pollen, contains a toxic substance called grayanotoxin. Depending on the dose, the poisonous honey can result in serious effects such as cardiac arrhythmia, fibrillation, and myocardial infarction. The purpose of this study is to investigate the effects of the poisonous RH of the Black Sea Region on the liver. Male mice were divided into five groups of twelve mice each, two being the control groups (distilled water) and the others being the rhododendron honey (RH) groups $(25,50$, and $75 \mathrm{mg} / \mathrm{kg}$ ) and $0.01 \mathrm{mg} / \mathrm{kg}$ grayanotoxin (GTx) groups. Liver tissues were collected 24 and $48 \mathrm{~h}$ later. The sections were stained with hematoxylin, eosin and PAS, then the histopathological score was performed. Significant statistical differences were observed between the RH and control groups in terms of congestion, steatosis, sinusoid dilatation, and inflammation. The control group demonstrated a normal liver structure in the light microscopy, while the GTx-applied $24 \mathrm{~h}$ group exhibited expansions in the sinusoids and congestion. Higher levels of congestion, steatosis, and inflammatory cells were seen in the GTx-applied $48 \mathrm{~h}$ group. In the same group, giant cells consisting of many nuclei were observed in the sinusoids. The results of the $25 \mathrm{mg}$ RH-applied groups were similar in 24 and 48 h, histopathological score levels were increased slightly, congestion and steatosis were prominent in the $48 \mathrm{~h}$ group. Dense steatosis was seen in the hepatocytes around the vena centralis in $50 \mathrm{mg} / \mathrm{kg} \mathrm{RH}$-applied $48 \mathrm{~h}$ group. Congestion, steatosis and an increase in inflammatory cells were observed in the hepatocytes in the $75 \mathrm{mg} / \mathrm{kg} \mathrm{RH}$-applied 24- and $48 \mathrm{~h}$ groups. PAS (+) stained hepatocytes were decreased in the RH- and GTx-applied groups. The toxic effects of the rhododendron honey were observed in the mice liver tissue with respect to dose and time.

KEY WORDS: Rhododendron honey; Mice; Liver.

\section{INTRODUCTION}

Rhododendron honey (mad honey), produced from the rhododendron genus growing in the Black Sea region, contains a toxic substance, grayanotoxin (Qiang et al., 2011; Gündüz et al., 2007; Koca \&Koca, 2007; Jansen et al., 2012). The history of RH poisoning goes back many years. Documents of Greek, Persian, Russian, and Pontus origin tell of cases of RH poisoning (Dossey, 2015). RH, known as an exotic plant in the British Empire, was referred to in Shakespeare's Macbeth. Poisonings and deaths in goats and sheep have been reported by veterinarians (Pain, 2015). There are 800-850 species of Rhododendron. Most are nontoxic, and most are found in the Black Sea region of Turkey, the Himalaya, China, and Southwest Asia, with some in regions of Europe and North America (Bhattacharyya 2011). Forest Rose honey is mostly produced from the rhododendron plant found especially in the Black Sea region of Turkey. Frequently seen toxic rhododendrons in Turkey are $R$. luteum and $R$. ponticum. Toxic rhododendrons in western North America are Western azalea (R. occidentale), California rosebay (R. macrophyllum), and $R$. albiforum; species of eastern North America are mountain laurel (Kalmia latifolia) and sheep laurel (Kalmia angustifolia) (Gündüz et al. 2007). Other rhododendron species are frequently seen throughout a large part of the Alps, in the Caucasus Mountains and Himalayas in the East, in Papua New Guinea in Indonesia, and Mount Bellenden Ker in Australia. The poisoning effect of the honey made from these plants is thought to derive from a grayanotoxin compound found in the nectar, pollen, flower, and leaves of some rhododendron species of the Ericaceae family (Ascioglu \&

\footnotetext{
* University of Abant Izzet Baysal, Faculty of Medicine, Department of Histology and Embryology, Bolu, Turkey.

** University of Düzce, Faculty of Agriculture and Natural Sciences, Department of Biosystems Engineering, Düzce, Turkey.

*** University of Düzce, Faculty of Science, Department of Biology, Düzce, Turkey.

**** University of Düzce, Faculty of Science, Department of Biology, Düzce, Turkey.
} 
Özesmi, 1995; Koca \& Koca). A total of 80 different types of the grayanotoxin contained in rhododendrons have been identified. It is a GTx fat-soluble toxin, shows its effect via voltage-dependent $\mathrm{Na}^{+2}$ channels, and increases $\mathrm{Na}^{+2}$ conductivity (Yaylaci et al., 2014). The effect of rhododendron honey depends on the dose, and while nausea, sweating, dizziness, and hypotension have been monitored in small doses, cardiac arrhythmia, fibrillation, and myocardial infarction have occurred with large doses. Findings occur within $20 \mathrm{~min}$ to $3 \mathrm{~h}$, without frequent eating, and the effects last for 1-2 days (Jansen et al.; Popescu \& Kopp, 2013). While the most common symptoms are bradycardia, hypotension, nausea, and dizziness, arrhythmia and heart blockage are seen in severe cases (Sohn et al., 2014; Silici \& Atayoglu 2015; Dur et al., 2014; Chen et al., 2014; Erenler, 2016). Although rhododendron honey is toxic, it is popularly used therapeutically for diabetes, arthritis, acute and chronic bronchitis, asthma, the common cold, gastrointestinal disorders, hypertension, and sexual dysfunction (Silici \& Atayoglu). Studies showed that it has anti-inflammatory, antimicrobial, antiviral, antibacterial, analgesic, antihyperglycemic, anti hyperlipidemic, hepato protective, cardio protective, anti protozoal, and sedative effects. Popescu \& Kopp wrote a detailed compilation of the subject. Although there are studies on the clinical and biochemical effects of rhododendron honey, few studies have analyzed the structural effects in tissue. This study will analyze the effect of rhododendron honey from the Düzce/ West Black Sea Region of Turkey in different doses and durations on mouse liver tissue, on a light microscopic level.

\section{MATERIAL AND METHOD}

All experimental protocols were performed according to the guidelines for the ethical treatment of experimental animals and were approved by the Animal Care and Use

Table I. Parameters assessed in liver injury score.

\begin{tabular}{lll}
\hline Stea tosis & $<5 \%$ & 0 \\
& $5-33 \%$ & 1 \\
& $>33-66 \%$ & 2 \\
Inflammation cells & $>66 \%$ & 3 \\
& None & 0 \\
& Scatter ed, easily seen & 1 \\
& Scatter ed in most lobules & 2 \\
Necrosis & Dense clusters & 3 \\
Sinusoidal dilatation & Absent & 0 \\
& Present & 1 \\
Congestion & Absent & 0 \\
& Present & 1 \\
& Absent & 0 \\
& Present & 1
\end{tabular}

Local Ethics Committee of Abant Izzet Baysal University, School of Medicine (2013/32).

Eight- to 12-week-old male Mus musculus (20-25 g) were housed at a constant room temperature $\left(22 \pm 2{ }^{\circ} \mathrm{C}\right)$ under a 12-h light/dark cycle. They were fed standard mice chow $(210 \mathrm{kcal} / 100 \mathrm{~g} /$ day $)$ and drank tap water. Five groups were arranged:

1. Control Groups $(\mathrm{n}=12)$ : Received $1 \mathrm{ml}$ oral distillated water only.

2. Received $25 \mathrm{mg} / \mathrm{kg} / \mathrm{day}$ oral rhododendron honey groups $(\mathrm{n}=12)$

3. Received $50 \mathrm{mg} / \mathrm{kg} /$ day oral rhododendron honey ( $\mathrm{n}=$ 12)

4. Received $75 \mathrm{mg} / \mathrm{kg} /$ day oral rhododendron honey $(\mathrm{n}=$ 12)

5. Received $0.01 \mathrm{mg} / \mathrm{kg} /$ day ip grayanotoxin $(\mathrm{n}=12)$

Solutions in different concentrations, prepared with rhododendron honey $(\mathrm{RH})$ from Düzce (West Black Sea, Turkey), were dissolved in water and given by gavage to the mice in $0.01 \mathrm{ml}$ per gram ratio (Silici 2014). 18 Test subjects of group 5 were given grayanotoxin-III (GTx) (Grayanotoxin, Lot 3-H1 293B-Enzo), approximately onetenth the rate of the concentration LD50, which is 0.908 $\mathrm{mg} / \mathrm{kg}$, so a $0.01 \mathrm{mg} / \mathrm{kg}$ dose intraperitoneally (Kaplan et al., 2014; Öztasan et al., 2005). Liver tissue samples were taken under anesthesia from half of the test subjects of each group after $24 \mathrm{~h}$ and the other half after 48 hours, which were identified with $10 \%$ neutral formalin. The tissues were subjected to routine processing and paraffin blocks were prepared. $5 \mu \mathrm{m}$ thick slices were taken and stained with hematoxylin-eosin and PAS. All tissue sections of each test subject were enlarged with $\mathrm{x} 20$ amplification and histopathologically scored as shown in Table I (Kleiner et al., 2005).

Statistical Analysis. The SPSS 13.00 for Windows software package was used for the statistical analysis of the gathered data. Data pertaining to the groups were compared using the non-parametric Kruskal-Wallis test, whereas the groups were compared with each other using the Mann-Whitney U-test. Differences were considered significant if p-values of less than 0.05 were obtained.

\section{RESULTS}

Histopathological scoring results between the control groups and the groups receiving rhododendron honey in different doses have been given in Table II. No significant 
Table II. Liver injury score in experimental groups. Values are expressed as Mean \pm Standard Deviation ( $\mathrm{p}<0.05)$.

\begin{tabular}{lccccc}
\hline Groups & Necrosis & Congestion & Steatosis & Sinusoidal dilatation & Inflammation cell \\
\hline Control & 0 & 0 & 0 & 0 & 0 \\
$25 \mathrm{mg} / \mathrm{kg} \mathrm{RH} \mathrm{24} \mathrm{h}$ & 0 & $0.50 \pm 0.548$ & $0 \pm 0.516$ & $0 \pm 0.516$ & 0 \\
$25 \mathrm{mg} / \mathrm{kg} \mathrm{RH} \mathrm{48} \mathrm{h}$ & 0 & $1 \mathrm{a}$ & $1 \pm 0.516$ & $0 \pm 0.516$ & $0 \pm 0.516$ \\
$50 \mathrm{mg} / \mathrm{kg} \mathrm{RH} \mathrm{24} \mathrm{h}$ & 0 & $1 \mathbf{b}$ & $1 \pm 0.516 \mathrm{~b}$ & $0 \pm 0.516$ & $0 \pm 0.516$ \\
$50 \mathrm{mg} / \mathrm{kg} \mathrm{RH} \mathrm{48} \mathrm{h}$ & $0 \pm 0.516$ & $1 \pm 0.408^{\mathbf{c}}$ & $1 \pm 0.753 \mathrm{c}$ & $0 \pm 0.516 \mathrm{c}$ & $2 \pm 1.169 \mathrm{c}$ \\
$75 \mathrm{mg} / \mathrm{kg} \mathrm{RH} \mathrm{24} \mathrm{h}$ & $0 \pm 0.516$ & $1 \pm 0.408^{\mathbf{d}}$ & $1.50 \pm 1.049^{\mathbf{d}}$ & $1 \pm 0.408^{\mathbf{d}}$ & $1 \pm 0.983^{\mathbf{d}}$ \\
$75 \mathrm{mg} / \mathrm{kg} \mathrm{RH} \mathrm{48} \mathrm{h}$ & $0.50 \pm 0.548$ & $1^{\mathbf{e}}$ & $1 \pm 0.753 \mathrm{e}$ & $1 \pm 0.408^{\mathbf{e}}$ & $1.50 \pm 0.378^{\mathbf{e}}$ \\
GTx 24 h & 0 & $0.50 \pm 0.548$ & $0 \pm 0.516$ & $0 \pm 0.516$ & $0 \pm 0.408^{\mathbf{f}}$ \\
GTx 48 h & 0 & $1 \pm 0.408 \mathrm{~g}$ & $1 \pm 0.516$ & $0 \pm 0.516$ & $0 \pm 0.408^{\mathbf{h}, \mathbf{i}}$ \\
\hline
\end{tabular}

$\mathrm{a}, \mathrm{b}, \mathrm{c}, \mathrm{d}, \mathrm{e}, \mathrm{g}=$ Compared with control group.

$\mathrm{f}=$ Difference between $75 \mathrm{mg} / \mathrm{kg}$ RH 24-hour group and GTx 24-hour group. $\mathrm{h}=$ Difference between $75 \mathrm{mg} / \mathrm{kg} \mathrm{RH}$ 48-hour group and GTx 24-hour group. $\mathrm{i}=$ Difference between $50 \mathrm{mg} / \mathrm{kg}$ RH 48-hour group and GTx 48-hour group.

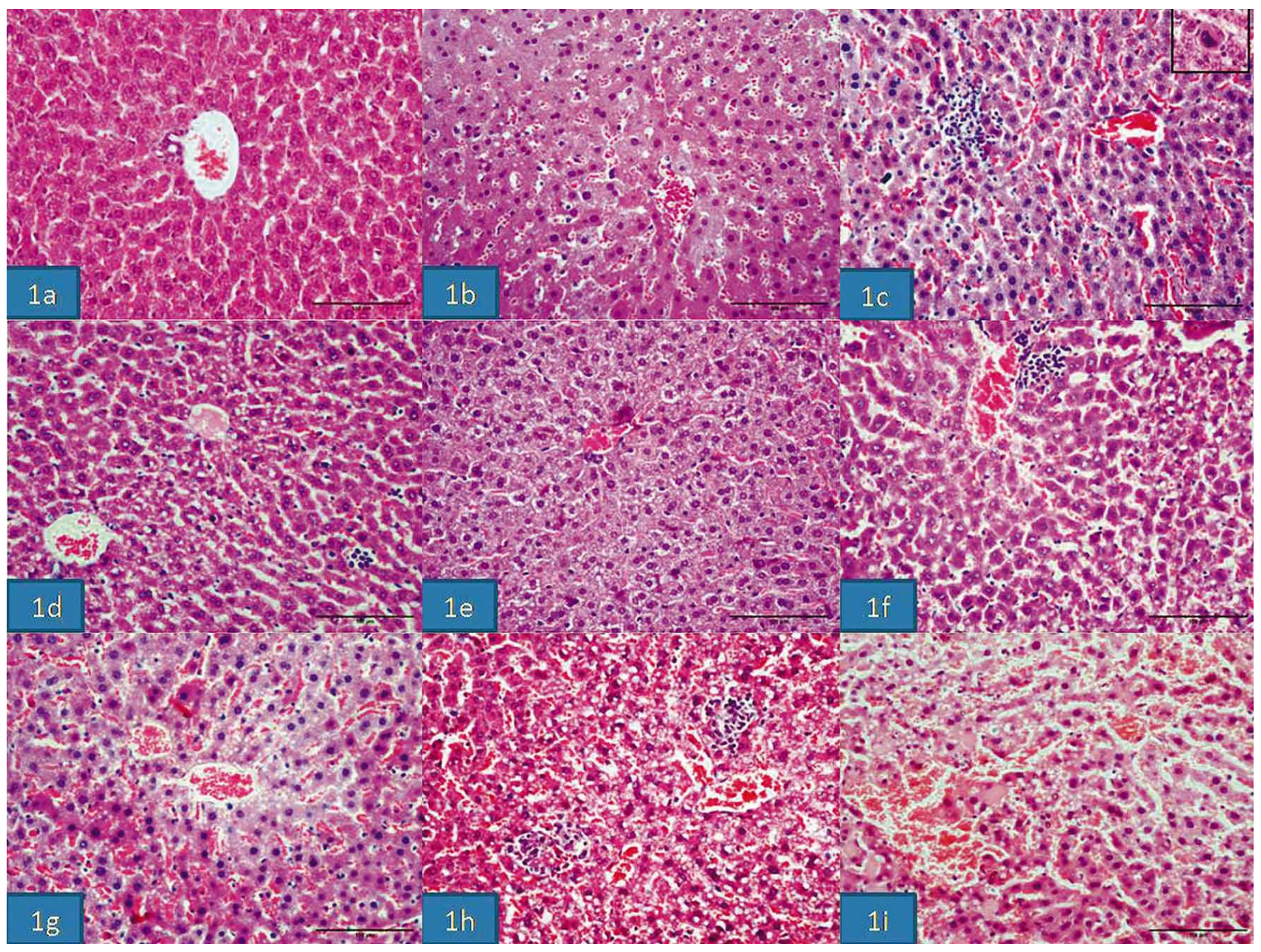

Fig. 1. Light microscopy images of liver tissues of the groups. Control group with normal structure (1a). $24 \mathrm{~h}$ GTx injected group (1b) and $48 \mathrm{~h}$ GTx injected group (1c) with increased congestion and inflammatory cell and expanded sinusoids. In the sinusoids, multinuclear giant macrophage cell (1c upper picture) is seen in $48 \mathrm{~h}$ GTx injected group. Steatosis, congestion and sinusoidal expansion are seen in $24 \mathrm{~h} 25 \mathrm{mg} / \mathrm{Kg} \mathrm{RH}$ given group (1d) and $48 \mathrm{~h} 25 \mathrm{mg} / \mathrm{Kg}$ RH given group (1e); increasing inflammatory cells are found in $24 \mathrm{~h} 50 \mathrm{mg} /$ $\mathrm{Kg}$ RH given group (1f) and $48 \mathrm{~h} 50 \mathrm{mg} / \mathrm{kg} \mathrm{RH}$ given group (1g); results are severe than other groups in $75 \mathrm{mg} / \mathrm{Kg} 24 \mathrm{~h} \mathrm{RH}$ (1h) ve 75 $\mathrm{mg} / \mathrm{Kg} 48 \mathrm{~h} \mathrm{RH}$ (1i) (Hematoxylin and eosin staining; Bar $100 \mu \mathrm{m})$. 


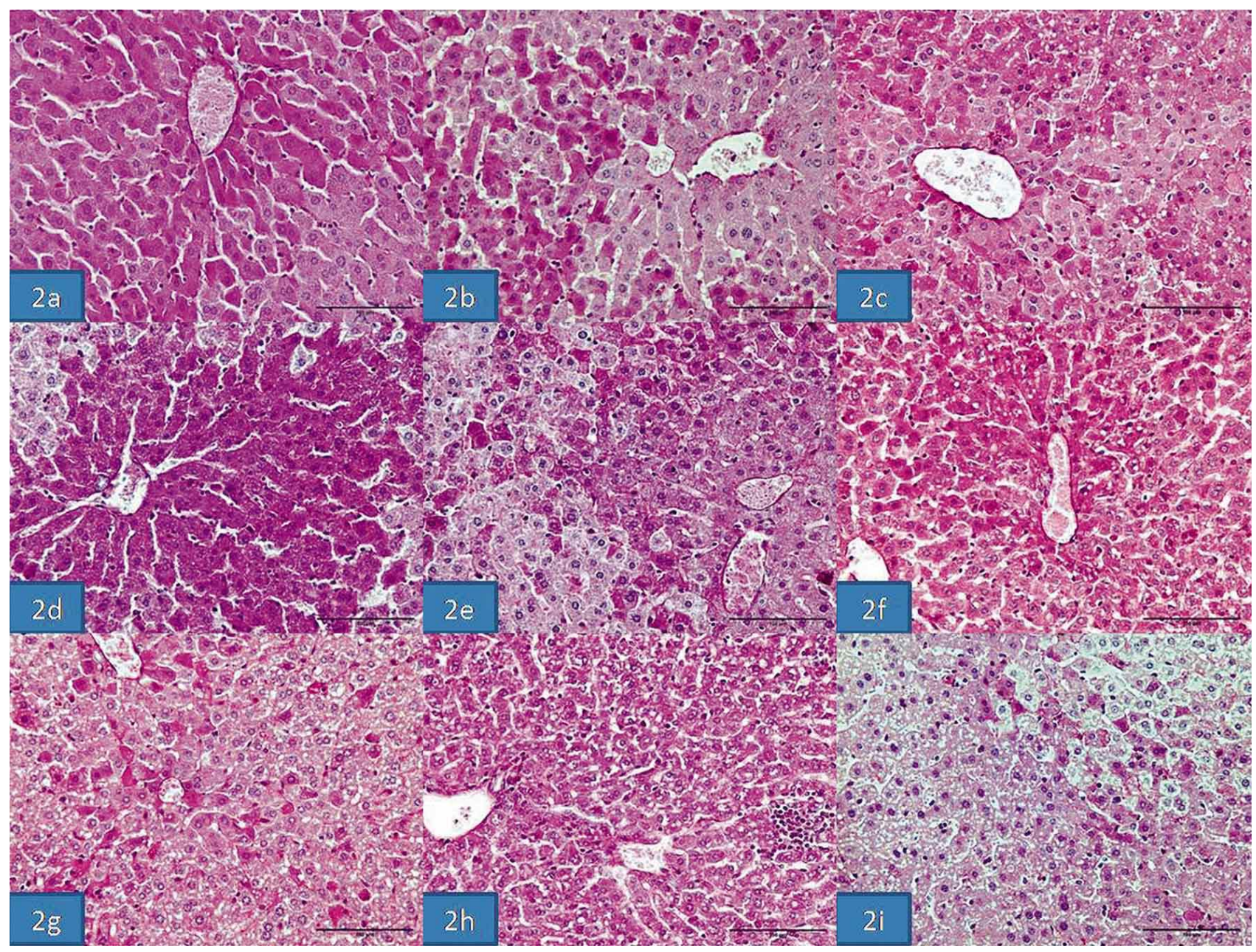

Fig. 2. Periodic Acid Shiff staining on the liver tissues. In control groups, hepatocytes are stained PAS positive (2a), while the staining decreased in group GTx (2b, 2c). Groups $25 \mathrm{mg} / \mathrm{Kg} \mathrm{RH}$ are stained almost same with group GTx (2d, 2e). PAS (+) hepatocytes of group GTx $48 \mathrm{~h}$ (2h, 2i) are stained less than 50 mg/Kg RH 24 h (2f) and 75 mg/Kg RH groups (2g) (PAS staining; Bar $100 \mu \mathrm{m}$ ).

difference between the 24-hour GTx $25 \mathrm{mg} / \mathrm{kg}$ honey group and the control group has been seen. Comparison of the control group with the GTx-applied 48-hour, $25 \mathrm{mg} / \mathrm{kg} \mathrm{RH}$-applied 48-hour, $50 \mathrm{mg} / \mathrm{kg}$ RH-applied 24- and 48-hour, $75 \mathrm{mg} / \mathrm{kg}$ RH-applied 24- and 48-hour groups has shown an increase in congestion, and comparison with $50 \mathrm{mg} / \mathrm{kg}$ and $75 \mathrm{mg} / \mathrm{kg} \mathrm{RH}$ applied groups has shown an increase in steatosis and inflammatory cells. The increase of inflammatory cells has been found significant in the $50 \mathrm{mg} / \mathrm{kg} \mathrm{RH}$-applied 48-hour group in comparison to the GTx-applied 48-hour group. The increase in inflammatory cells has been found significant in the $75 \mathrm{mg} / \mathrm{kg} \mathrm{RH}$-applied 24- and 48-hour group in comparison to the GTx-applied 24- and 48-hour groups. Steatosis values have shown similarity in all groups except the 24-hour GTx group (Table II). Light microscopic examination revealed that the liver tissue looked normal in the control group (Fig. 1a) and that there were expanded sinusoids and congestion in the GTx-applied 24-hour group (Fig. 1b). Steatosis and inflammatory cells have increased in the GTx-applied 48-hour group when compared to the 24-hour group (Fig. 1c). Multinucleated giant cells in the sinusoids (macrophages) have been determined in this group (Fig. 1c, small picture). Findings of the $25 \mathrm{mg} / \mathrm{kg} \mathrm{RH}$-applied 24-hour and 48-hour groups are similar. Congestion and steatosis was more prominent in the 48-hour group (Fig. 1d and 1e). When compared with the 50 $\mathrm{mg} / \mathrm{kg} \mathrm{RH}$-applied 24-hour group (Fig. 1f), it has been seen that in the $50 \mathrm{mg} / \mathrm{kg}$ RH-applied 48-hour group the effect on the liver tissue is distinct and the steatosis in the hepatocytes around the vena centralis is intense (Fig. 1g). An increase in necrotic cells, congestion, steatosis, and inflammatory cells in the liver tissue of the $75 \mathrm{mg}$ honey-applied 24-hour group has been determined (Fig. 1h). Findings significantly increased in the $75 \mathrm{mg} / \mathrm{kg} \mathrm{RH}$-applied 48-hour group and necrotic cells could be evidently selected (Fig. 1i). Necrotic cells could be defined only in the $75 \mathrm{mg} / 48$-hour group. No fibrosis or cirrhotic changes have been determined in any of the groups. 
It has been determined that Periodic Acid Shiff (PAS) staining showed widespread positively stained hepatocytes in the control group (Fig. 2a), and a decrease in the GTx groups (Fig. 2b and 2c), and that the staining in the $25 \mathrm{mg} /$ $\mathrm{kg}$ RH-applied groups is similar to that of the GTx groups (Fig. $2 \mathrm{~d}$ and 2e). It has been monitored that the PAS (+) stained hepatocyte number significantly decreased in the 48hour groups (Fig. $2 \mathrm{~g}$ and 2i) in comparison to the $50 \mathrm{mg} / \mathrm{kg}$ (Fig. 2f) and $75 \mathrm{mg} / \mathrm{kg} \mathrm{RH}$ - (Fig. 2h) applied 24-hour group.

\section{DISCUSSION}

This study has determined that different doses of $\mathrm{RH}$ have shown structural changes in mouse liver tissue depending on dose and duration. The number of studies of structural effects of RH on liver tissue is relatively small. Most of the studies take place on a clinical or biochemical level (Koca \& Koca; Yaylaci et al.; Dur et al.; Eroglu et al., 2013). Silici \& Atayoglu analyzed study results from PubMed, Scopus, Web of Science, and Google Scholar databases relating to this subject from the years 1981-2014. It has been determined that $75 \%$ of poisonings happen in men, mostly causing dizziness, nausea, presyncope, sinus bradycardia in ECG, AV block, ST elevation, and nodal rhythm, that there have been no cases of death, and that patients returned to normal within $24 \mathrm{~h}$ after a liquid and atropine treatment. The blood, heart, lung, liver, kidney, testis, epididymis, spleen, and brain tissues of rats, applied with different dosages of $\mathrm{RH}$, have been biochemically oxidative examined. The MDA, CAT, SOD, and GSH-PHx activities in the blood and tissue samples have shown negative effects on the antioxidant parameters in the groups with GTx and high doses of RH (Silici \& Atayoglu ). Rats that have been applied with different doses of RH for 8 days have shown an increase in liver enzymes (Sahin et al., 2015). It has been reported that RH has a hepatoprotective effect and that the R. Arboreum species decreases cholesterol and triglycerides (Prakesh et al., 2008; Verma et al., 2011). While it has been found that $50 \mathrm{mg}$ RH significantly decreased glucose and lipid levels in rats with experimental diabetes (Öztasan et al.; Verma et al., 2012). Uzun et al. (2013) found that RH doesn't have any effect on blood glucose levels in humans. The PAS (+) staining we carried out in our study to show glycogen in hepatocytes determined that the hepatocyte number was lower in comparison to the control group and especially to the 50 $\mathrm{mg} / \mathrm{kg}$ and $75 \mathrm{mg} / \mathrm{kg} \mathrm{RH}$-applied 48-hour groups. Our results show parallels to the results of Öztasan et al. The RH dose, duration, and type used in the studies are influential for the results. It has been reported that one teaspoon R. genus (ponticum and luteum) is consumable for humans, that 100 $\mathrm{mg} / \mathrm{kg}$ is a low and $2.5 \mathrm{~g} / \mathrm{kg}$ a high dose (Silici \& Atayoglu). In light of this information we used 25,50 , and $75 \mathrm{mg} / \mathrm{kg} \mathrm{RH}$ doses in our study. The RH we used, belonging to the region of Düzce, has been analyzed by Kaplan et al., and the GTx level has been identified. It has been found that the GTx concentration is $7.4 \mathrm{mg} / \mathrm{kg}$ (Kaplan et al.). The GTx III inside the RH is toxic. It acts through all $\mathrm{Na}$ channels in the muscle and nerve cell membranes and develops paralysis (Erenler). With each GTx dose we used on mice in this study, no neurological defect or death has occurred. Although it has been histologically determined that $100 \mathrm{mg} / \mathrm{kg} \mathrm{RH}$ in rats doesn't affect the liver functions in the 1-hour acute phase, no result in the liver tissue has been reported (Silici \& Atayoglu). Despite our RH doses being lower, changes in the liver tissue, depending on dose and duration, have been observed, especially an increase of steatosis around the vena centralis, a widespread congestion in sinusoids, and an increase in inflammatory cells. While the effect of the $25 \mathrm{mg} / \mathrm{kg} \mathrm{RH}$ dose was slightly observable, the $50 \mathrm{mg} / \mathrm{kg}$ and $75 \mathrm{mg} / \mathrm{kg}$ RH doses showed an increased effect and the 48-hour group showed significant distinguished changes. Inflammatory cell increase has been significantly determined in the $50 \mathrm{mg} / \mathrm{kg} \mathrm{RH}$-applied 48-hour group and $75 \mathrm{mg} / \mathrm{kg} \mathrm{RH}$-applied 24- and 48-hour groups in comparison to the GTx group. Especially the GTx 48-hour group showed a large number of multinucleated giant cells. The GTx inside the RH has been observed to be more prominent in the groups applied with GTx. As a result, depending on the $\mathrm{RH}$ dose and duration, we conclude that $\mathrm{RH}$ honey from the Düzce/West Black Sea region causes degenerative changes in the livers of mice.

KÜKNER, A.; ILTER, G.; SÖYLER, G.; RASGELE, P. G.; KEKEÇOGLU, M \& KAMBUR, M. Efecto de la miel de rododendro en el tejido hepático de ratón. Int. J. Morphol., 34(3):842-847, 2016.

RESUMEN: La miel de rododendro, elaborada por las abejas a partir del polen de rododendro, contiene una sustancia tóxica llamada grayanotoxina. Dependiendo de la dosis, la miel venenosa puede resultar en efectos graves, tales como arritmia cardiaca, fibrilación e infarto de miocardio. El propósito de este estudio fue investigar los efectos en el hígado de la miel venenosa de rododendro de la región del Mar Negro. Se distribuyeron ratones machos en cinco grupos de doce ratones cada uno, dos grupos control (agua destilada) y los otros grupos se trataron con la miel de rododendro (MR) $(25,50$ y $75 \mathrm{mg} / \mathrm{kg})$ y con $0,01 \mathrm{mg} / \mathrm{kg}$ grayanotoxina (GTX). Los tejidos hepáticos se recogieron 24 y 48 h más tarde. Las secciones fueron teñidas con hematoxilina-eosina y PAS. A continuación, se realizó la puntuación histopatológica. No se observaron diferencias estadísticamente significativas entre MR y los grupos de control en términos de congestión, esteatosis, dilatación sinusoidal e inflamación. El grupo control demostró una estructura normal del hígado en el microscopio de luz, mientras que el grupo de las 24 horas de aplicación de GTX exhibió expansiones en los sinusoides y congestión. Mayores niveles de congestión, esteatosis y células inflamatorias se observaron en el grupo de 48-horas de aplicación de GTX. En el mismo grupo, se observaron células gigantes que consistían en la presencia de muchos núcleos en los sinusoides. Los resultados de los grupos con aplicación de $25 \mathrm{mg}$ de RH fueron similares en los resultados de 24 y $48 \mathrm{~h}$, los 
niveles de puntuación histopatológica aumentaron ligeramente, la congestión y la esteatosis fueron prominentes en el grupo de $48 \mathrm{~h}$. Se observó esteatosis densa en los hepatocitos en toda la vena central en el grupo de aplicación de $50 \mathrm{mg} / \mathrm{kg}$ de RH, 48 h. La congestión, la esteatosis y un aumento en las células inflamatorias se observaron en los hepatocitos en el grupo de $75 \mathrm{mg} / \mathrm{kg}$ de MR de $24 \mathrm{~h}$ y los grupos de $48 \mathrm{~h}$. Hepatocitos teñidos con PAS (+) disminuyeron en los grupos de GTX y MR. Se observaron los efectos tóxicos de la miel de rododendro en el tejido hepático de ratones con respecto a la dosis y el tiempo.

\section{PALABRAS CLAVE: Miel de Rododendro; Ratón; Hígado.}

\section{REFERENCES}

Ascioglu, M. \& Özesmi, Ç. Grayanotoxin content of honey samples from Black Sea Region of Turkey. Hamdard Med., 38(3):42-7, 1995.

Bhattacharyya, D. Rhododendron species and their uses with special reference to Himalayas - A Review. Assam Univ. J. Sci. Technol., 7(1):161-7, 2011.

Chen, S. P.; Lam, Y. H.; Ng, V. C.; Lau, F. L.; Sze, Y. C.; Chan, W. T. \& Mak, T. W. Mad honey poisoning mimicking acute myocardial infarction. Hong Kong Med. J., 19(4):354-6, 2013.

Dossey, L. Mad Honey: Reflections on Sweetness, Death, and the Politics of Healthcare. Explore (N. Y.), 11(5):333-41, 2015.

Dur, A.; Sonmez, E.; Civelek, C.; Ahmet Turkdogan, K.; AkifVatankulu, M. \& Sogut O. Mad honey intoxication mimicking acute coronary syndrome. J. Pak. Med. Assoc., 64(9):1078-80, 2014.

Erenler, A. K. Cardiac Effects of mad honey poisoning and its management in emergency department: A review from turkey. Cardiovasc. Toxicol., 16(1):1-4, 2016

Eroglu, S. E.; Urgan, O.; Onur, O. E.; Denizbası, A. \& Akoglu, H. Grayanotoxin (mad honey) - ongoing consumption after poisoning. Balkan Med. J., 30(3):293-5, 2013.

Gunduz, A.; Bostan, H.; Turedi, S.; Nuhoglu, I. \& Patan, T. Wild flowers and mad honey. Wilderness Environ. Med., 18(1):69-71, 2007.

Jansen, S. A.; Kleerekooper, I.; Hofman, Z. L.; Kappen, I. F.; StaryWeinzinger, A. \& van der Heyden, M. A. Grayanotoxin poisoning: 'mad honey disease' and beyond. Cardiovasc. Toxicol., 12(3):208-15, 2012.

Kaplan, M.; Olgun, E. O. \& Karaoglu, O. Determination of grayanotoxins in honey by liquid chromatography tandem mass spectrometry using dilute-and-shoot sample preparation approach. J. Agric. Food Chem., 62(24):5485-91, 2014.

Kleiner, D. E.; Brunt, E. M.; Van Natta, M.; Behling, C.; Contos, M. J.; Cummings, O. W.; Ferrell, L. D.; Liu, Y. C.; Torbenson, M. S.; UnalpArida, A.; Yeh, M.; McCullough, A. J.; Sanyal, A. J. \& Nonalcoholic Steatohepatitis Clinical Research Network. Design and validation of a histological scoring system for nonalcoholic fatty liver disease. Hepatology, 41(6):1313-21, 2005.

Koca, I. \& Koca, A. F. Poisoning by mad honey: a brief review. Food Chem. Toxicol., 45(8):1315-8, 2007.
Öztasan, N.; Altinkaynak, K.; Akçay, F.; Göçer, F. \& Dane, S. Effects of mad honey on blood glucose and lipid levels in rats with streptozocininduced diabetes. Turk. J. Vet. Anim. Sci., 29(5):1093-6, 2005.

Pain, S. Sweet deceit. New Sci., 226(3018):42-5, 2015.

Popescu, R. \& Kopp, B. The genus Rhododendron: an ethnopharmacological and toxicological review. J. Ethnopharmacol., 147(1):42-62, 2013.

Prakesh, T.; Fadadu, S. D.; Sharma, U. R.; Surendra, V.; Goli, D.; Stamina, P. \& Kotresha, D. Hepatoprotective activity of leaves of Rhododendron arboreum in $\mathrm{CCl} 4$ induced hepatotoxicity in rats. J. Med. Plants Res., 2(11):315-20, 2008

Qiang, Y.; Zhou, B \& Gao, K. Chemical constituents of plants from the genus Rhododendron. Chem. Biodivers., 8(5):792-815, 2011.

Sahin, H.; Yildiz, O. \& Kolayli, S. Effects of mad honey on some biochemical parameters in rats. J. Evid. Based Complementary Altern. Med., pii:2156587215596430, 2015.

Silici, S. \& Atayoglu, A. T. Mad honey intoxication: A systematic review on the 1199 cases. Food Chem. Toxicol., 86:282-90, 2015.

Sohn, C. H.; Seo, D. W.; Ryoo, S. M.; Lee, J. H.; Kim, W. Y.; Lim, K. S. \& Oh, B. J. Clinical characteristics and outcomes of patients with grayanotoxin poisoning after the ingestion of mad honey from Nepal. Intern. Emerg. Med., 9(2):207-11, 2014.

Uzun, H.; Narci, H.; Tayfur, I.; Karabulut, K. U. \& Karcioglu, O. Mad honey intoxication: what is wrong with the blood glucose? a study on 46 patients. Eur. Rev. Med. Pharmacol. Sci., 17(20):2728-31, 2013.

Verma, N.; Singh, A. P.; Amresh, G.; Sahu, P. K. \& Rao, Ch. V. Protective effect of ethyl acetate fraction of Rhododendron arboreum flowers against carbon tetrachloride-induced hepatotoxicity in experimental models. Indian J. Pharmacol., 43(3):291-5, 2011.

Verma, N.; Amresh, G.; Sahu, P. K.; Rao, Ch. V. \& Singh, A. P. Antihyperglycemic and antihyperlipidemic activity of ethyl acetate fraction of Rhododendron arboreum Smith flowers in streptozotocin induced diabetic rats and its role in regulating carbohydrate metabolism. Asian Pac. J. Trop. Biomed., 2(9):696-701, 2012.

Yaylaci, S.; Kocayigit, I.; Aydin, E.; Osken, A.; Genc, A. B.; Cakar, M. A. \& Tamer, A. Clinical and laboratory findings in mad honey poisoning: a single center experience. Niger. J. Clin. Pract., 17(5):589-93, 2014.

\author{
Correspondence to: \\ Prof. Dr. Aysel Kukner MD \\ Abantl'zzetBaysal University \\ Medicine Faculty \\ Histology and Embryology Department \\ Bolu \\ TURKEY
}

Email: akukner@hotmail.com

Received: 22-02-2016

Accepted: 22-06-2016 